\title{
MECHANICAL AND MATHEMATICAL MODELING OF THE LOAD MOVEMENT ON THE THREAD WOUND ON CYLINDRICAL DRUM WITH MOVABLE AXIS
}

\author{
Serhii Podliesnyi; Mykola Dorokhov; Oleksandr Stadnyk; Yurii Yerfort
}

\author{
Donbass State Engineering Academy, Kramatorsk, Ukraine
}

\begin{abstract}
Summary. A mechanical system, where the load in the form of material point is suspended on inextensible thread screwed on the rotating cylindrical drum, but the drum is connected to the boom rotating around fixed horizontal axis is considered. Using the Lagrange equation of the second kind, a mathematical model of the motion of the mechanical system is obtained. The system has three degrees of freedom, two of which are cylindrical. The investigation of the system motion is carried out using computer technology. As a result, the dependences of linear and angular coordinates and velocities in time at different values of the output data for two main modes of the system operation, namely - under the conditions of lifting and lowering the load are obtained. Appropriate graphs are constructed, including the trajectories of the cargo motion. The mathematical model takes into account nonlinearities of the system and allows you to find the amount of tension of the hoisting rope at any time. The analysis showed that vertical oscillations occur twice as fast as horizontal ones. The phase portrait of the generalized coordinate (angle of the rope with the vertical axis) is the focus, which is untwisted when lifting due to nonlinearity in the system, and when the load moves down, the focus, which twists and approaches the mathematical pendulum is obtained. The obtained results can be used in modeling of controlled pendulum motions for different mechanical systems. The methodology and program are recommended to the students and graduate students in terms of learning the principles of construction and analysis of complex nonlinear dynamical systems.
\end{abstract}

Key words: oscillations, nonlinear dynamics, phase portrait, pendulum, mathematical model, Lagrange equations of the second kind, d'Alembert principle, numerical experiment.

Statement of the problem. Mathematical models of pendulum systems are used to describe a wide class of processes. Many objects due to their dynamics are different types of pendulum installations (and in some cases - and their combination), and the requirement of stability is a primary requirement for their operation. First of all, this applies to various types of lifting mechanisms, such as tower, bridge, gantry, cantilever, frame-portal and other cranes.

For example, tower cranes are the most widely used among building cranes, which perform the task of mechanization of loading and unloading operations on the construction site. However, their fault rate is $40 \%$ of the total number of accidents of jib cranes. Tower cranes collapse can occur even if all operating rules and safety requirements are observed. At present the development and further improvement of tower cranes is impossible without the innvestigation of loads and their impact on strength under different operating conditions. The strength of cranes depends on many significant factors, such as wind load, lifting weight, dynamic loads, weight of cantilevered parts. The dynamic loads that follow the operation of any crane are the most significant while performing operations combined with load lifting, which can result in its slacking.

Taking into account the above mentioned, the investigation of the behavior of complex pendulum systems, such as the cargo movement in the joint lifting mechanisms operation is an important problem. 
Analysis of the available investigations and publications. Intensive investigations in the field of pendulum systems modeling using various software packages of computer algebra are constantly being carried out. For example, various models of spherical pendulum [1-2], oscillations of the pendulum with variable length [3] and variable mass [4] were considered. There are many examples and mechanical systems in the scientific literature, which consider load oscillations in the lifting mechanisms [5-9].

The motion of reversible mathematical pendulum with variable thread length is investigated in paper [10]. For the development of this investigation, it is proposed to consider complicated mechanical system, closer to the systems of hoisting machines, when the axis of the cylindrical drum is fixed on rotating arrow.

The objective of the paper. Development and investigation of the model of load oscillating motion on the thread wound on cylindrical drum, which axis is fixed on the rotating boom.

Statement of the task. Let us consider the motion of mechanical system, where the material point $\mathrm{M}$ of mass $m$ is suspended on inextensible thread screwed on cylindrical drum with radius $R$. The length of the hanging link of the thread in the equilibrium position before the motion start is equal to $\ell_{0}$. The cylinder rotates at a constant angular velocity $\omega$. The drum axis is connected to an arrow with length $r$, which rotates at a constant angular velocity $\Omega$ $\Omega$ (Fig. 1). The thread mass is neglected.

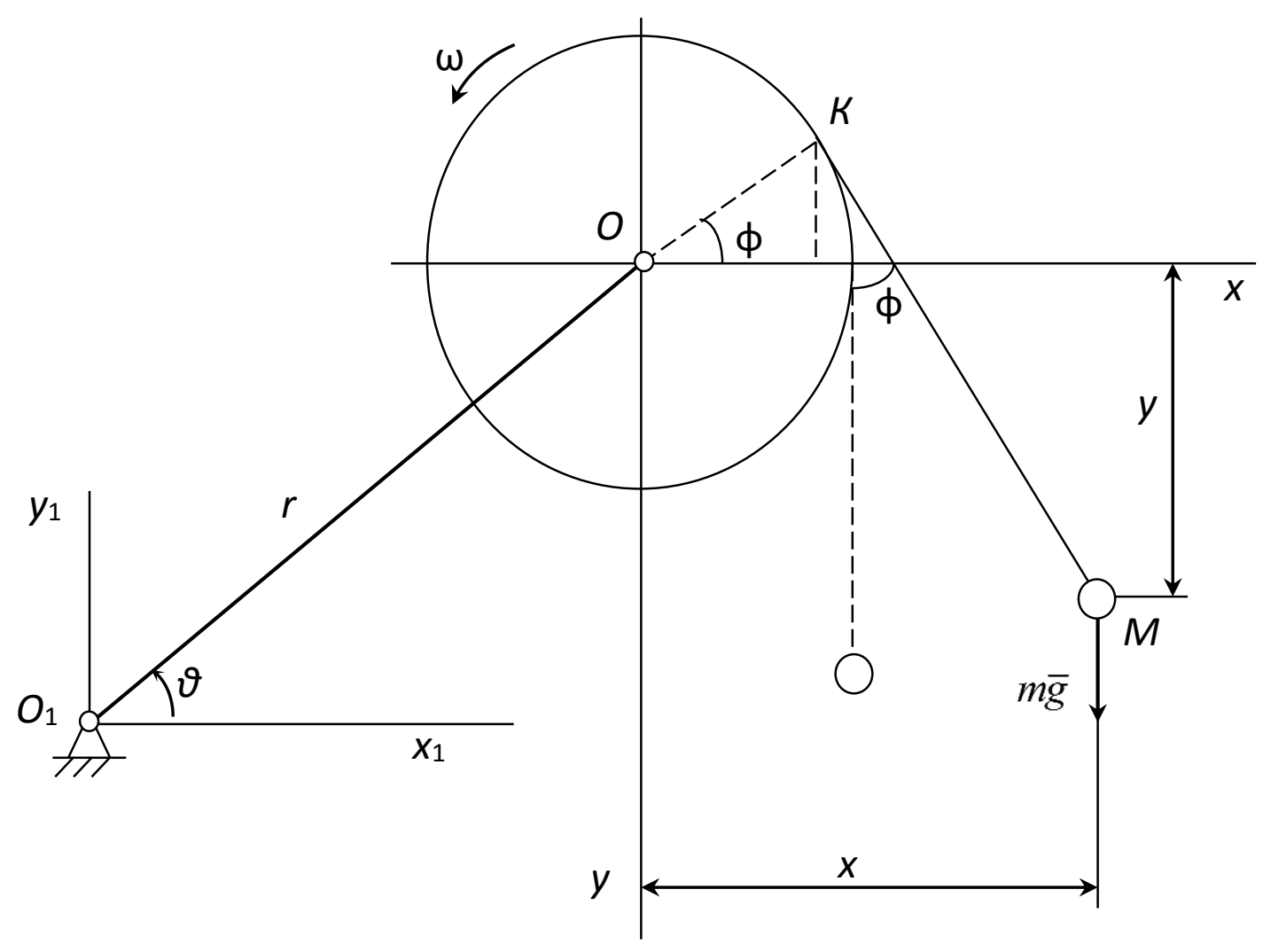

Figure 1. Scheme of load oscillations on the rope wound on cylindrical drum attached to the rotary boom

Presentation of the basic material of the investigation with substantiation of the obtained scientific results. In order solve the problem we investigate the system kinematics. 
Cartesian coordinates of the material point $M$ :

$$
\begin{gathered}
x_{1}=x_{0}+x, \quad x=R \cos \varphi+\left(\ell_{0}-R \omega t+R \varphi-R \Omega t\right) \sin \varphi, \\
y_{1}=y_{0}-y, \quad y=\left(\ell_{0}-R \omega t+R \varphi-R \Omega t\right) \cos \varphi-R \sin \varphi, \\
x_{0}=r \cos \Theta, \quad y_{0}=r \sin \Theta, \quad \Theta=\Omega t .
\end{gathered}
$$

Then

$$
\begin{aligned}
& x_{1}=r \cos (\Omega t)+R \cos \varphi+\left(\ell_{0}-R \omega t+R \varphi-R \Omega t\right) \sin \varphi, \\
& y_{1}=r \sin (\Omega t)+R \sin \varphi-\left(\ell_{0}-R \omega t+R \varphi-R \Omega t\right) \cos \varphi .
\end{aligned}
$$

The velocity of the point $v$ is found by the projections on the coordinate axis.

Let us write Lagrange equation of the second order:

$$
\frac{d}{d t}\left(\frac{\partial T}{\partial \dot{\varphi}}\right)-\frac{\partial T}{\partial \varphi}=Q_{\varphi}
$$

where kinetic energy and generalized force are:

$$
T=\frac{m v^{2}}{2}, \quad Q_{\varphi}=-\frac{\partial \Pi}{\partial \varphi} .
$$

Using (1), (2) and (4) let us write equation (3) taking into account the terms of the given task:

$$
\begin{aligned}
& \left(\ell_{0}-R \omega t+R \varphi-R \Omega t\right)^{2} \frac{d^{2} \varphi}{d t^{2}}+\left[R\left(\frac{d \varphi}{d t}\right)^{2}-2 R(\Omega+\omega) \frac{d \varphi}{d t}-\Omega^{2} r \cos (\varphi-\Omega t)+\right. \\
& +g \sin \varphi]\left(\ell_{0}-R \omega t+R \varphi-R \Omega t\right)=0 .
\end{aligned}
$$

Knowing the load speed by means of D'Alembert principle, we can find the tension of the hoisting rope at any time:

$$
N=m g \cos \varphi+m \ell \dot{\varphi}^{2}
$$

Setting the numerical values of the system parameters and initial conditions: $\ell_{0}=20 \mathrm{~m}$, $r=10 \mathrm{~m}, R=0.4 \mathrm{~m}, g=9.81 \mathrm{~m} / \mathrm{s}^{2}, \varphi_{0}=0.1 \mathrm{rad} ., \varphi_{0}=0.1 \mathrm{~s}^{-1}$; let us carry out calculations and build graphs during cargo lifting.

The graphs of changes in individual parameters of the system at $\omega=1.6 \mathrm{~s}^{-1}$ and different values of $\Omega: 1-0.02 \mathrm{~s}^{-1}, 2-0.05 \mathrm{~s}^{-1}, 3-0.1 \mathrm{~s}^{-1}, 4-0.15 \mathrm{~s}^{-1}, 5-0.2 \mathrm{~s}^{-1}$ are shown in Figures 2-7. 


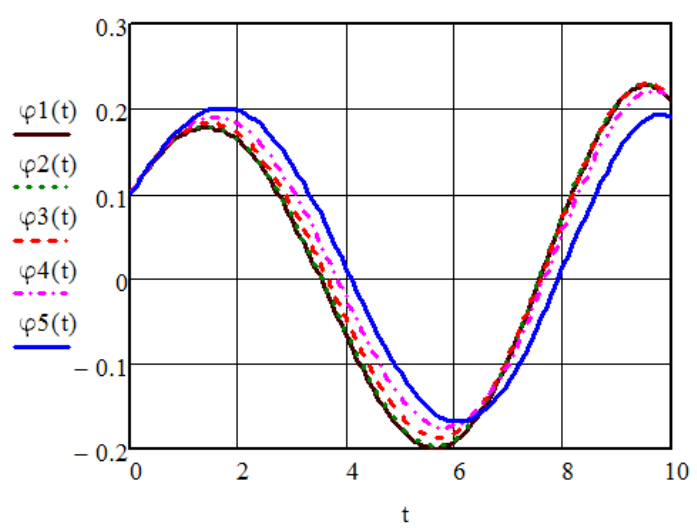

Figure 2. Dependency graph $\varphi(t)$

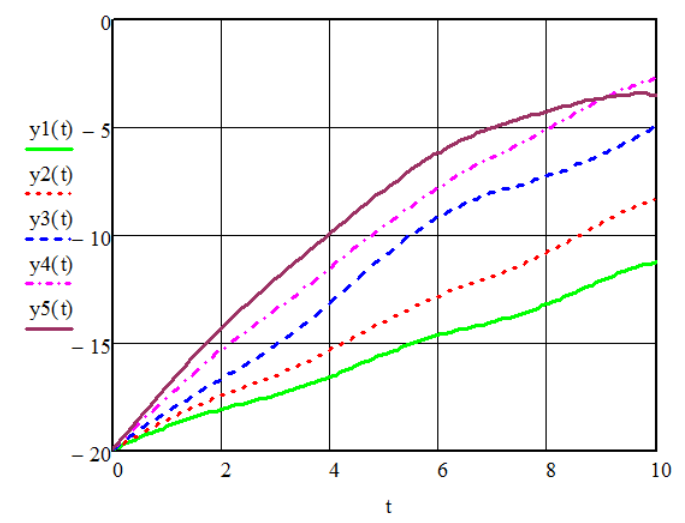

Figure 4. Dependency graph $y(t)$

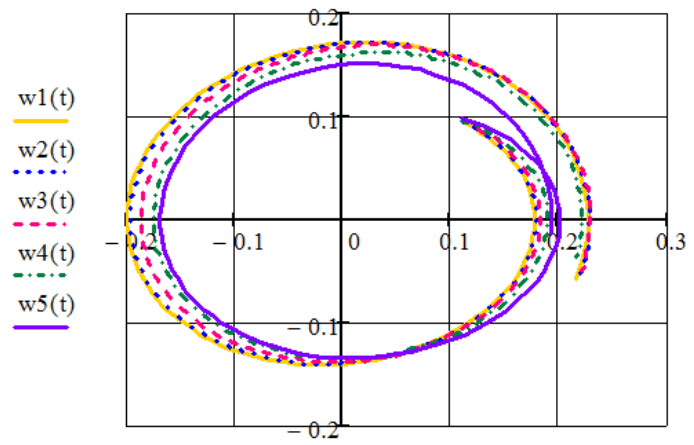

$\varphi 1(t), \varphi 2(t), \varphi 3(t), \varphi 4(t), \varphi 5(t)$

Figure 6. Phase portrait: $\omega(t)-\varphi(t)$

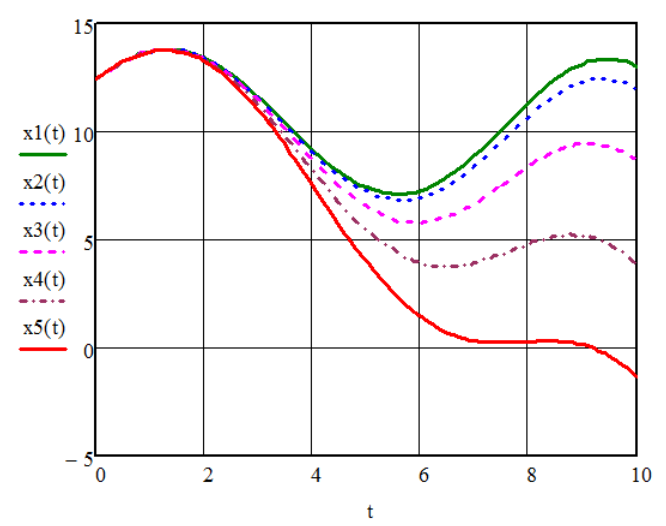

Figure 3. Dependency graph $x(t)$

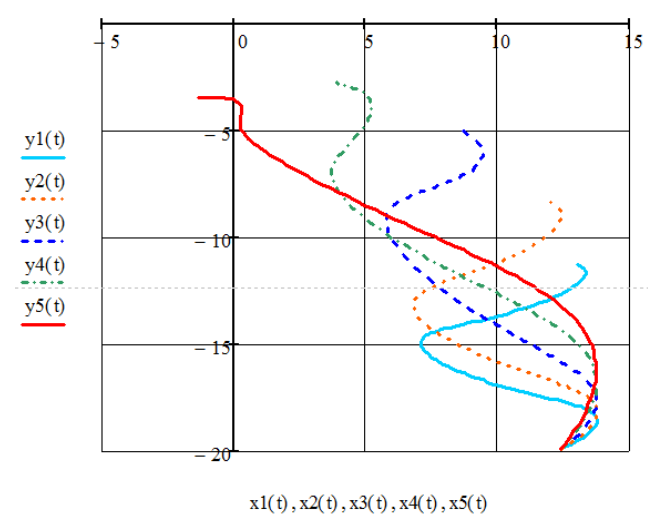

Figure 5. Load movement trajectory: $y(t)-x(t)$

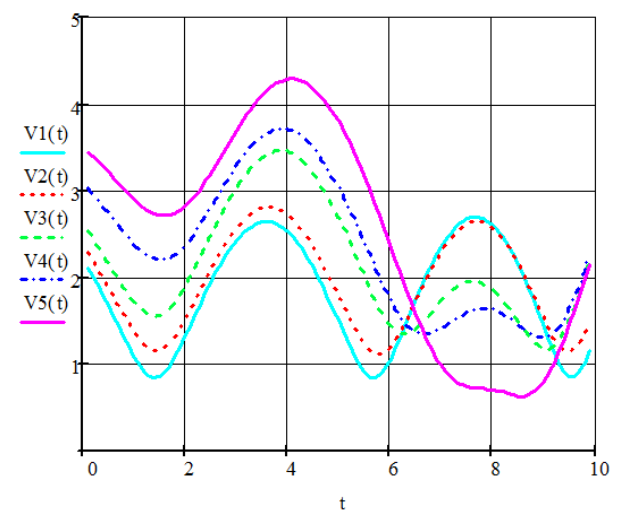

Figure 7. Speed change graph $v(t)$

The graphs of changes in the same parameters of the system at $\Omega=0,05 \mathrm{~s}^{-1}$ and different values of $\omega$ : $6-0.1 \mathrm{~s}^{-1}, 7-0.2 \mathrm{~s}^{-1}, 8-0.4 \mathrm{~s}^{-1}, 9-0.8 \mathrm{~s}^{-1}, 10-1.6 \mathrm{~s}^{-1}$ are shown in Figures 8-13. 


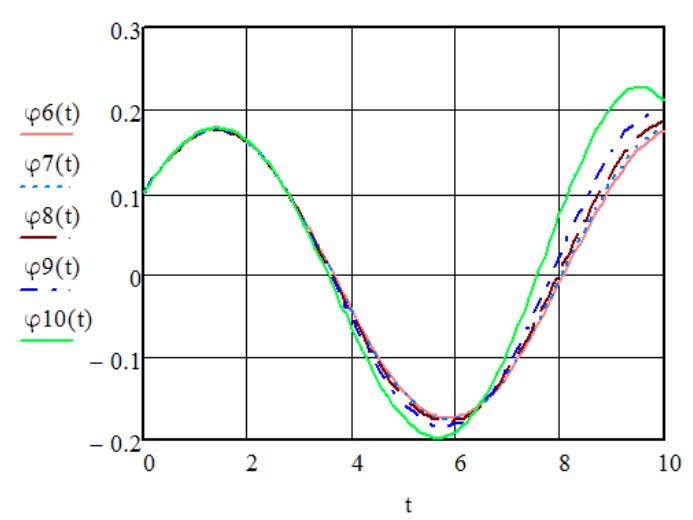

Figure 8. Dependency graph $\varphi(t)$

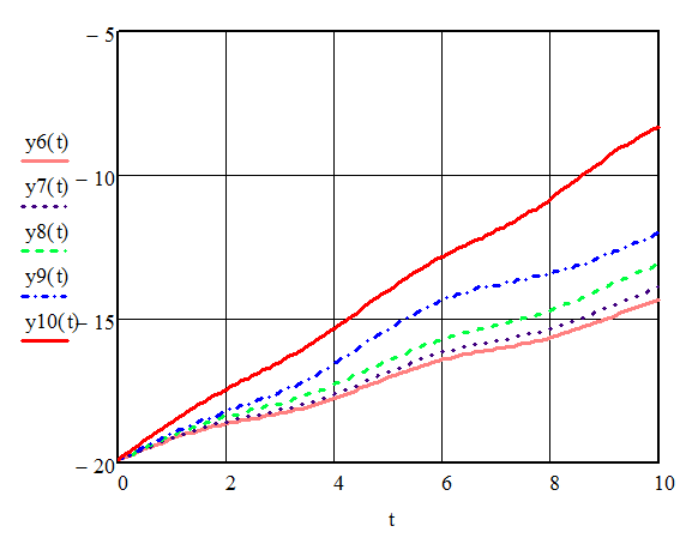

Figure 10. Dependency graph $y(t)$

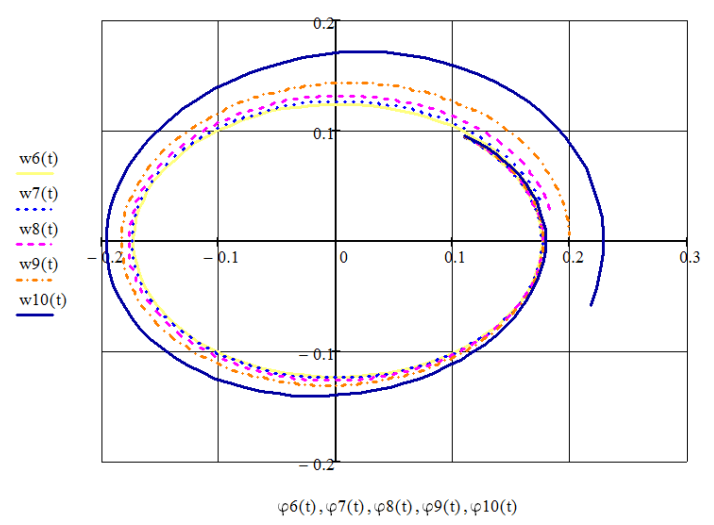

Figure 12. Phase portrait: $\omega(t)-\varphi(t)$

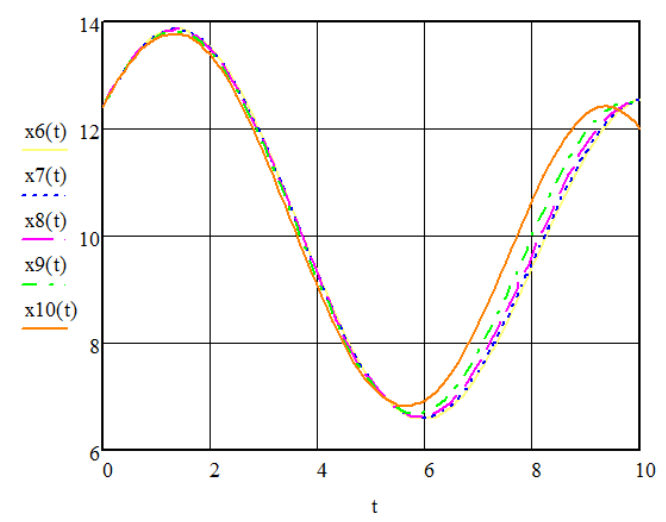

Figure 9. Dependency graph $x(t)$

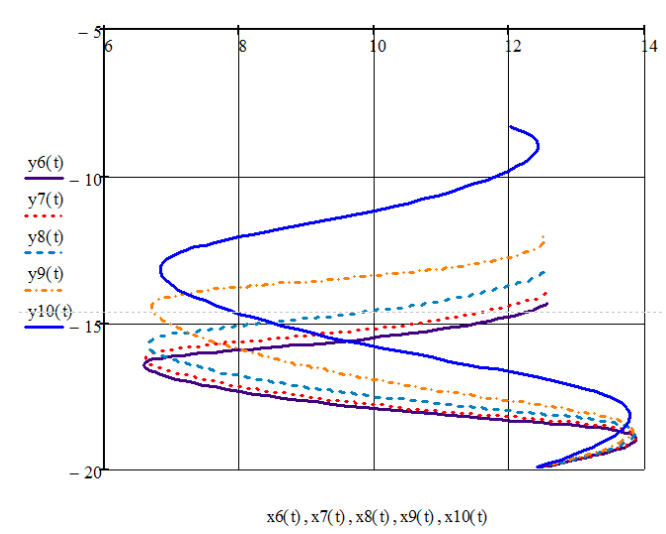

Figure 11. Load movement trajectory: $y(t)-x(t)$

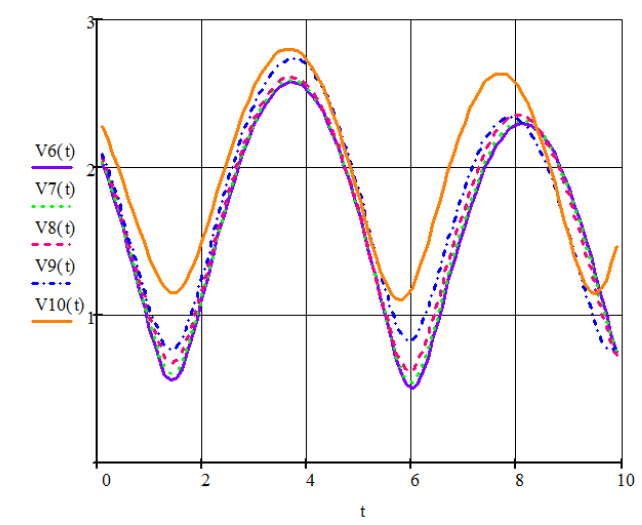

Figure 13. Speed change graph $v(t)$

While lifting the load, the reduction in rope length is small $(\Delta \ell \approx R \varphi)$. The angle $\varphi$ of the drum rotation and the horizontal displacement are related approximately by the ratio $x \approx \ell \varphi$ and their change coincides with the oscillation of the simple mathematical pendulum with $\ell \approx \ell_{0} \approx 20 \mathrm{~m}$ length with the period of approximately $9 \mathrm{sec}$. The amplitude of these oscillations is constant and is 0.25 radians for $\varphi$ and about $8 \mathrm{~m}$ for $x$ and is 
slightly shifted in the negative direction because the center of the drum is also shifted to the left by $(r-r \cos \theta)$ value. For $\Omega=0.2 \mathrm{~s}^{-1}$ of the boom angular velocity for $10 \mathrm{sec}$. the angle of rotation is $\theta=2 \mathrm{rad} \approx 120^{\circ}$ and the load moves to the left by about 15 meters. Its coordinate along the axis $x$ becomes approximately $10+4-15=-1 \mathrm{~m}$, which corresponds to Fig. 3.

The coordinate $y$ increases monotonically by the value $\Delta y \approx R \omega t+r \theta$ and oscillations occur around this line due to the movement of the load along the axis $x$. But these oscillations have the period $\tau=4.5 \mathrm{~s}$ twice less than the horizontal ones, because during one period of the horizontal motion there are two oscillations along the vertical. In fig. 4 and 10 we see The change of coordinate $y$ in time cab be seen in Fig. 4 and 10.

The trajectories in Cartesian coordinate system are shown in Fig. 5 and 11.

For small values of angular velocities $\Omega$ of the boom and $\omega$ of the drum, the load velocity practically does not change, and it increases when, for example, the rope length $\ell=\ell_{0}-\omega t$ decreases, because due to the kinetic moment the load velocity increases as the cable length $\ell$ decreases. Due to the internal forces during winding the rope and the moment applied to the boom for maintaining its angular velocity $\Omega$ there is kinetic energy «pumping» Fig. 7.

The phase portrait of the generalized coordinate $\varphi$ is the focus that is untwisted (Fig. 6 and 12).

Also the case when the angular velocity of the drum will be directed in the opposite direction, i.e. the thread will be wound from it, is of particular interest. In this case, the cargo coordinates are determined by the following equations:

$$
\begin{gathered}
x_{1}=r \cos (\Omega t)+R \cos \varphi+\left(\ell_{0}+R \omega t+R \varphi-R \Omega t\right) \sin \varphi \\
y_{1}=r \sin (\Omega t)+R \sin \varphi-\left(\ell_{0}+R \omega t+R \varphi-R \Omega t\right) \cos \varphi .
\end{gathered}
$$

And the differential equation of cargo motion is written in the following form:

$$
\begin{aligned}
& \left(\ell_{0}+R \omega t+R \varphi-R \Omega t\right)^{2} \frac{d^{2} \varphi}{d t^{2}}+3 R\left(\ell_{0}+R \omega t+R \varphi-R \Omega t\right)\left(\frac{d \varphi}{d t}\right)^{2}+ \\
& +\left(2 R \Omega r \sin (\varphi-\Omega t)+2 \Omega r\left(\ell_{0}+R \omega t+R \varphi-R \Omega t\right) \cos (\varphi-\Omega t)-2 R^{2}(\Omega-\omega) \varphi+\right. \\
& \left.+2 R^{2}(\Omega-\omega)^{2} t-2 R(\Omega-\omega) \ell_{0}\right) \frac{d \varphi}{d t}-2 R \Omega r(\Omega-\omega) \sin (\varphi-\Omega t)- \\
& -\Omega^{2} r\left(\ell_{0}+R \omega t+R \varphi-R \Omega t\right) \cos (\varphi-\Omega t)+g\left(\ell_{0}+R \omega t+R \varphi-R \Omega t\right) \sin \varphi=0
\end{aligned}
$$

Under the approximate condition $\omega R>\Omega r$, the load will be lowered.

Setting the numerical values of the system parameters and the initial conditions: $\ell_{0}=4 \mathrm{~m}$, $r=10 \mathrm{~m}, R=0,4 \mathrm{~m}, g=9.81 \mathrm{~m} / \mathrm{s}^{2}, \varphi_{0}=0.1 \mathrm{rad}$., $\varphi_{0}=0.1 \mathrm{~s}^{-1}$; let us carry out calculations and build graphs during the load lowering.

The graphs of changes in the parameters of the system motion (namely in time at $\omega=1.8 \mathrm{~s}^{-1}$ and different values of $\Omega: 1-0.01 \mathrm{~s}^{-1}, 2-0.02 \mathrm{~s}^{-1}, 3-0.04 \mathrm{~s}^{-1}, 4-0.06 \mathrm{~s}^{-1}$, $5-0.08 \mathrm{~s}^{-1}$ ) are shown in Figures 14-19. 


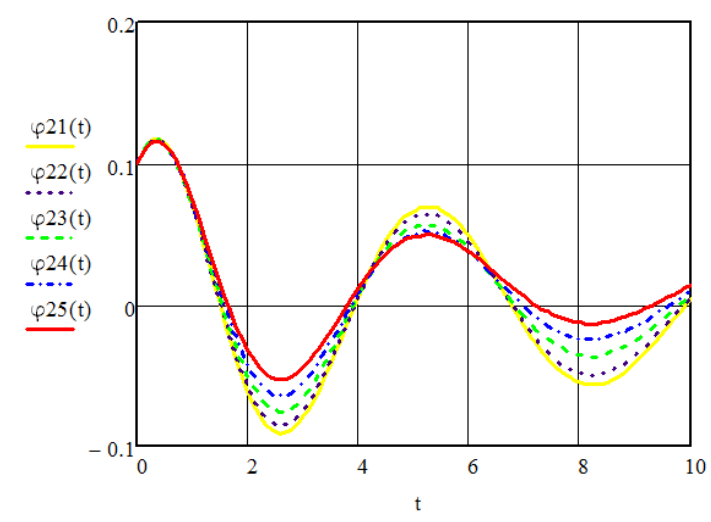

Figure 14. Dependency graph $\varphi(t)$

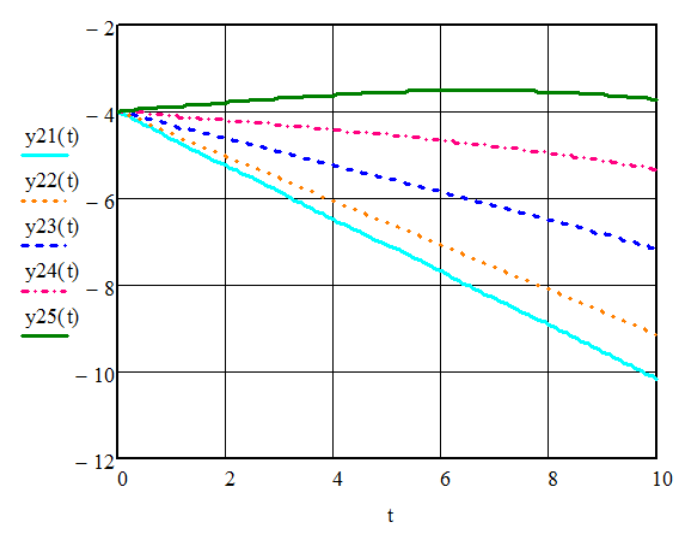

Figure 16. Dependency graph $y(t)$

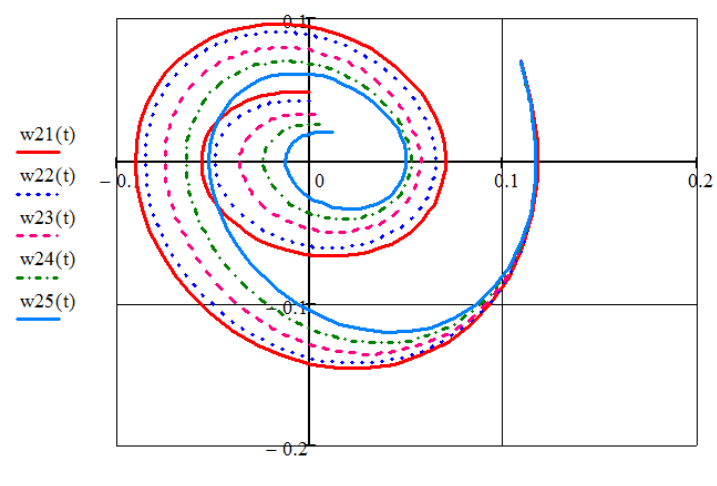

Figure 18. Phase portrait: $\omega(t)-\varphi(t)$

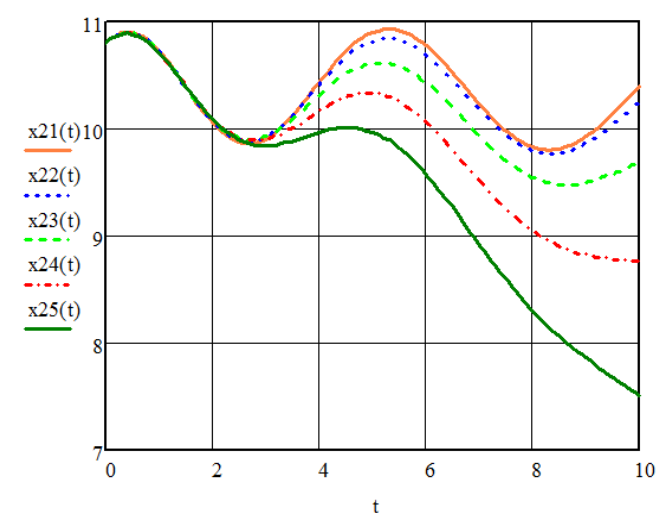

Figure 15. Dependency graph $x(t)$

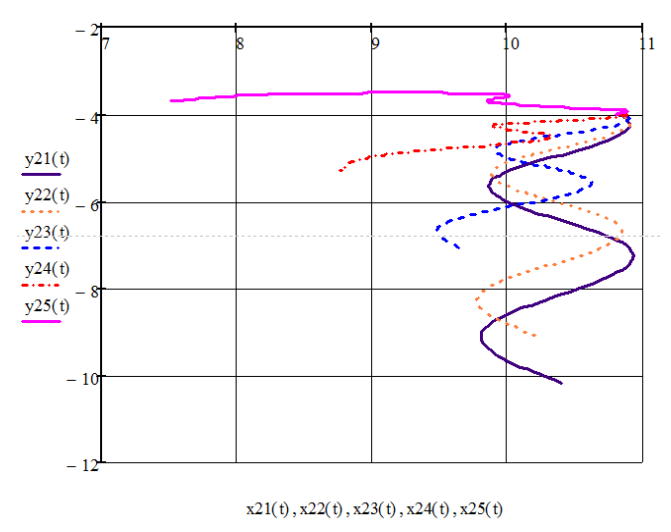

Figure 17. Load movement trajectory: $y(t)-x(t)$

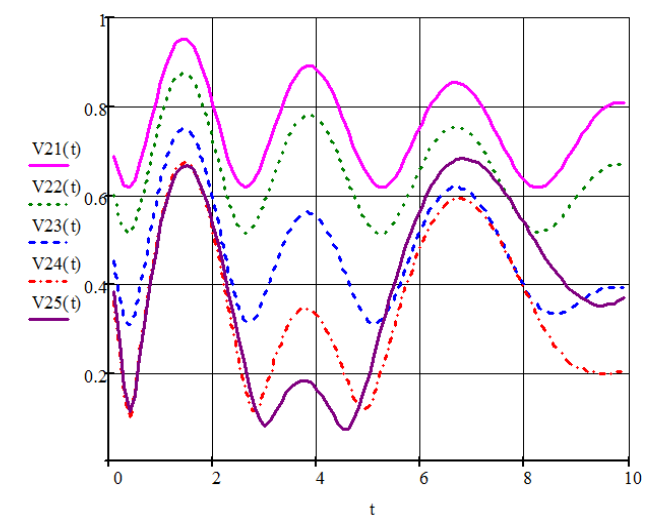

Figure 19. Speed change graph $v(t)$

The graphs of changes in the same parameters of the system at $\Omega=0.01 \mathrm{~s}^{-1}$ and different values of $\omega: 6-0.4 \mathrm{~s}^{-1}, 7-0.8 \mathrm{~s}^{-1}, 8-1.2 \mathrm{~s}^{-1}, 9-1.6 \mathrm{~s}^{-1}, 10-2.0 \mathrm{~s}^{-1}$ are shown in Figures 20-25. 


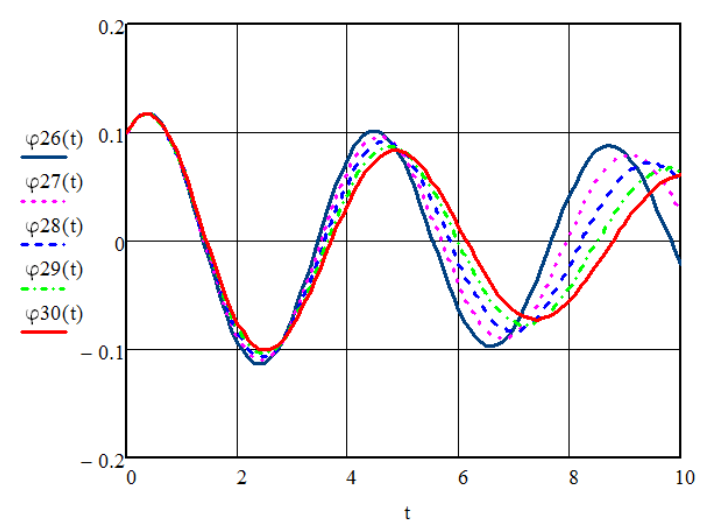

Figure 20. Dependency graph $\varphi(t)$

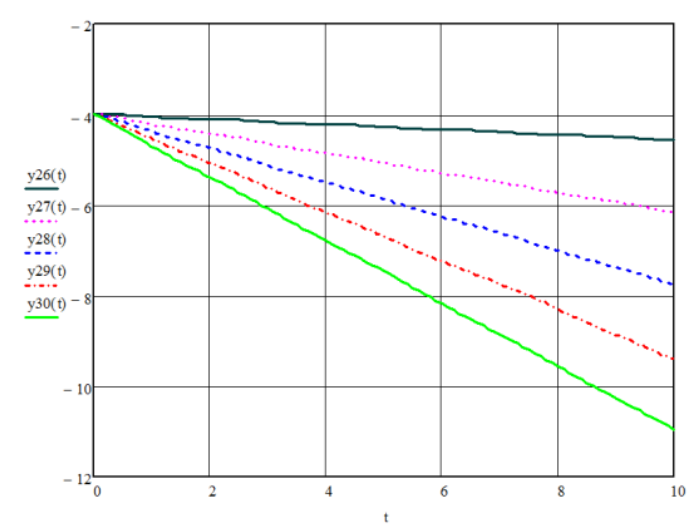

Figure 22. Dependency graph $y(t)$

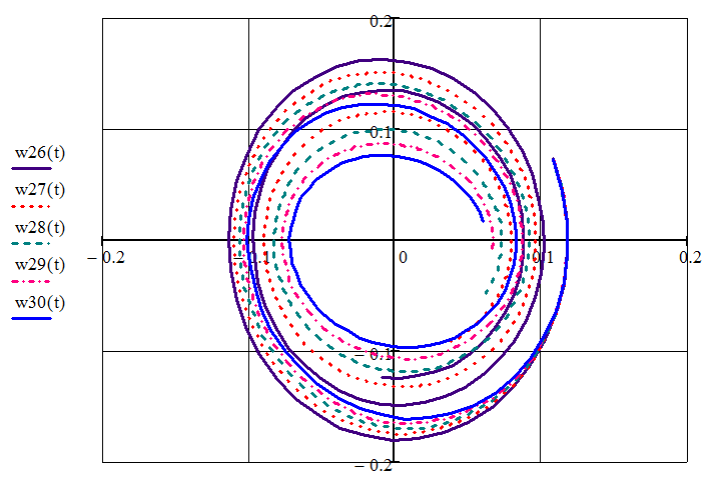

$\varphi 26(\mathrm{t}), \varphi 27(\mathrm{t}), \varphi 28(\mathrm{t}), \varphi 29(\mathrm{t}), \varphi 30(\mathrm{t})$

Figure 24. Phase portrait: $\omega(t)-\varphi(t)$

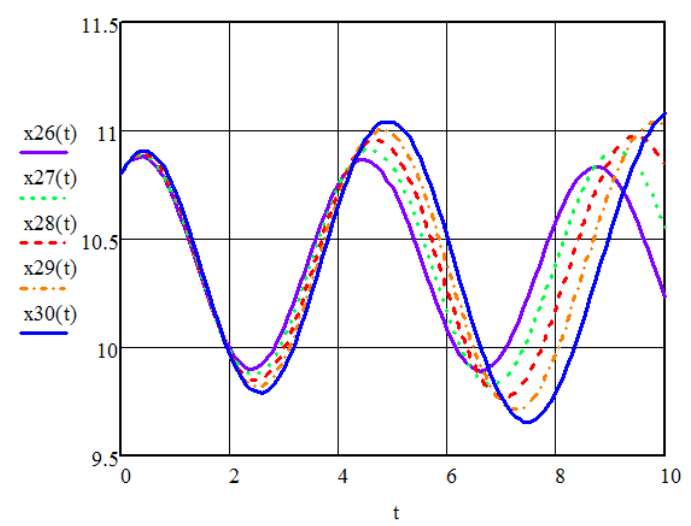

Figure 21. Dependency graph $x(t)$

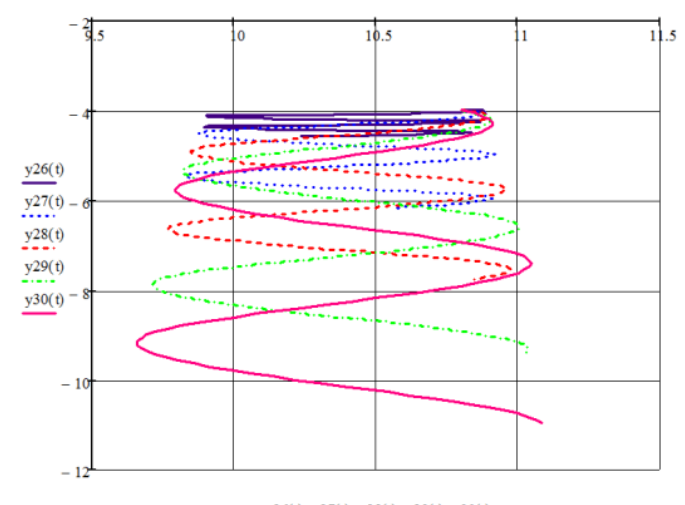

$x 26(t), x 27(t), x 28(t), x 29(t), x 30(t)$

Figure 23. Load movement trajectory: $y(t)-x(t)$

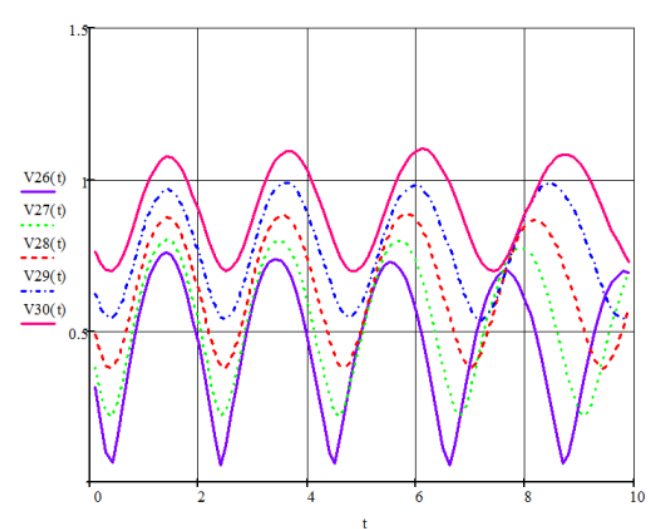

Figure 25. Speed change graph $v(t)$

The movement of the load to the bottom is shown in Fig. 14-25. The rope deviation angle $\varphi$ is not more than $30^{\circ}$ and decreases with time. The rope length $\ell \approx \ell_{0}+R \varphi$ increases, while the angle $\varphi$ decreases over time, but $x \approx \ell \varphi$ and oscillations increase. 
Mechanical and mathematical modeling of the load movement on the thread wound on cylindrical drum with movable axis

The period of horizontal oscillations is reduced to $5 \mathrm{sec}$. Depending on the angular velocity $\Omega$ of the crane boom, the center of oscillation moves slightly to the left as in the case of load lifting.

Vertical motion also occurs with the frequency twice that of horizontal motion. This is clearly seen in Fig. 19 and 25, where the period of cargo speed change is approximately $2.5 \mathrm{~s}$.

If $r \Omega \approx R \omega$, then the coordinate $y$ of the load does not change (Fig. 16), because the speed of the boom end to the mountain coincides with the speed of the rope winding. The speed and magnitude of the change in the coordinate $y$ are not as large as in the case of rope winding the because $\Omega$ and $\omega$ are opposite in direction.

Phase portrait is the twisting focus.

Velocity and kinetic energy are stable, which characterizes the system conservatism. The system nonlinearity is practically not detected while unwinding the rope.

Conclusions. The mechanical system load-drum-boom is considered and its mathematical model is developed. The system has three degrees of freedom, two of which are cyclic coordinates. Nonlinear differential equations of motion are integrated by means of computer and the dependence on coordinate time and cargo velocity is obtained. It should be noted that vertical oscillations along the vertical axis occur twice as fast as horizontal ones. Phase portraits are built du lifting and lowering the load. The phase portrait of the generalized coordinate $\varphi$ is the focus, which is untwisted during lifting due to nonlinearity in the system, and when the load moves down, the focus, which twists and approaches the mathematical pendulum is obtained.

\section{References}

1. Podlesny S. (2020) Dynamics of a spherical pendulum on a nonlinear elastic suspension under the action of a variable side aerodynamic load. Visnyk TNTU (Tern.). Vol. 98. No. 2. P. 49-58. DOI: https://doi.org/10.33108/visnyk_tntu2020.02.049

2. Freundlich J., Sado D. Dynamics of a coupled mechanical system containing a spherical pendulum and a fractional damper. Meccanica. Vol. 55. P. 2541-2553. URL: https://doi.org/10.1007/ s11012-020-012034(0123456789. DOI: https://doi.org/10.1007/s11012-020-01203-4

3. Zinko R. Maiatnyk zminnoi dovzhyny. Elektronnyi resurs. URL: http://www.zinko.lviv.ua/index.php? artid=1472900553.

4. Olshanskyi S. V. Nestatsyonarnye kolebanyia ostsylliatora peremennoi massy s uchytom viazkoho trenyia. Vibratsii v tekhnitsi ta tekhnolohiiakh. No. 3 (75). 2014. P. 18-27.

5. Loveikin V., Lymar P. Dynamichnyi analiz peremishchennia vizka vantazhopidiomnoho krana zi zmishchenym tsentrom mas vantazhu vidnosno zakhvatu. Visnyk TNTU. 2014. Tom 73. No. 1. P. 102-109.

6. Perig A. V., Stadnik A. N., Kostikov A. A., Podlesny S. V. Research into 2D dynamics and control of small oscillations of a cross-beam during transportation by two overhead cranes. Shock and Vibration. 2017. URL: http://downloads.hindawi.com/journals/sv/2017/9605657.pdf. DOI: https://doi.org/10.1155/2017/9605657

7. Loveikin V. S., Romasevych Yu. O., Stekhno O. V. Optymizatsiia rezhymu rukhu mekhanizmu zminy vylotu vantazhu bashtovoho krana z horyzontalnoiu striloiu. Mashynobuduvannia. 2017. No. 20. P. 11-18. DOI: https://doi.org/10.32820/2079-1747-2017-18-14-18

8. Podoliak O. S., Bolybik M. O. Matematychne modeliuvannia sumisnoho rukhu mekhanizmiv pidiomu, povorotu i zminy vylotu krana DEK-251. Mashynobuduvannia. 2017. No. 19. P. 61-67.

9. Palamarchuk D. A. Issledovanye dynamyky dvyzhenyia strelovoi systemy krana pry avtomatycheskom upravlenyy mekhanyzmom yzmenenyia vyleta. Visnyk Natsionalnoho universytetu vodnoho hospodarstva ta pryrodokorystuvannia. Vypusk 3 (67). 2014 r. Seriia “Tekhnichni nauky”. P. 361-370.

10. Bulatov L. A., Bertiaev V. D., Kyreeva A. E. Issledovanye dvyzhenyia oborotnoho matematycheskoho maiatnyka s yzmeniaiushcheisia dlynoi nyty. Yzvestyia TulHU. Tekhnycheskye nauky. 2010. Vol. 2. Ch. 1. P. 11-18.

\section{Список використаної літератури}

1. Podlesny S. Dynamics of a spherical pendulum on a nonlinear elastic suspension under the action of a variable side aerodynamic load. Visnyk TNTU (Tern.). 2020. Vol. 98. No. 2. P. 49-58. DOI: https://doi.org/10.33108/visnyk_tntu2020.02.049

2. Freundlich J., Sado D. Dynamics of a coupled mechanical system containing a spherical pendulum and a fractional damper. Meccanica. Vol. 55. P. 2541-2553. URL: https://doi.org/10.1007/ s11012-020-012034(0123456789. DOI: https://doi.org/10.1007/s11012-020-01203-4 
3. Зінько Р. Маятник змінної довжини. URL: http://www.zinko.lviv.ua/index.php?artid=1472900553.

4. Ольшанский C. В. Нестационарные колебания осциллятора переменной массы с учётом вязкого трения. Вібрації в техніці та технологіях. № 3 (75). 2014. С. 18-27.

5. Ловейкін В., Лимар П. Динамічний аналіз переміщення візка вантажопідйомного крана зі зміщеним центром мас вантажу відносно захвату. Вісник ТНТУ. 2014. Том 73. № 1. С. 102-109.

6. Perig A. V., Stadnik A. N., Kostikov A. A., Podlesny S. V. Research into 2D dynamics and control of small oscillations of a cross-beam during transportation by two overhead cranes. Shock and Vibration. 2017. URL: http://downloads.hindawi.com/journals/sv/2017/9605657.pdf. DOI: https://doi.org/10.1155/2017/9605657

7. Ловейкін В. С., Ромасевич Ю. О., Стехно О. В. Оптимізація режиму руху механізму зміни вильоту вантажу баштового крана з горизонтальною стрілою. Машинобудування, 2017. № 20. С. 11-18. DOI: https://doi.org/10.32820/2079-1747-2017-18-14-18

8. Подоляк О. С., Болибік М. О. Математичне моделювання сумісного руху механізмів підйому, повороту і зміни вильоту крана ДЕК-251. Машинобудування. 2017. № 19. С. 61-67.

9. Паламарчук Д. А. Исследование динамики движения стреловой системы крана при автоматическом управлении механизмом изменения вылета. Вісник Національного університету водного господарства та природокористування. Випуск 3 (67). 2014 р. Серія «Технічні науки». С. 361-370.

10. Булатов Л. А., Бертяев В. Д., Киреева А. Е. Исследование движения оборотного математического маятника с изменяющейся длиной нити. Известия ТулГУ. Технические науки. 2010. Вып. 2. Ч. 1. C. $11-18$.

\title{
УДК 531.3
}

\section{МЕХАНІКО-МАТЕМАТИЧНЕ МОДЕЛЮВАННЯ РУХУ ВАНТАЖУ НА НИТЦ, НАВЕРНУТОЇ НА ЦИЛІНДРИЧНИЙ БАРАБАН 3 РУХОМОЮ ВІССЮ}

\section{Сергій Подлссний; Микола Дорохов; Олександр Стадник; Юрій Єрфорт}

\section{Донбаська державна машинобудівна академія, Краматорськ, Украӥна}

\begin{abstract}
Резюме. Розглянуто механічну систему стріла та барабан, на який намотано трос з вантажем. Поліспаст замінено тросом незмінної довжени, крюкова система, стропи та вантаж приведено до єдиної маси. Маси частин механізму підйому, щзо обертаються, зведені до оголовка стріли. Отримано нелінійні диференціальні рівняння руху механічної системи за допомогою рівнянь Лагранжа друго роду. Вона має три ступеня вільності, два з яких ииклічні. Для аналізу використано чисельні методи. Досліджено вплив кутової швидкості стріли та кутової швидкості барабана на рух вантажу. Побудовано графіки залежності головних параметрів системи за часом, траєкторії, фазові портрети та амплітудно-частотні характеристики, коли вантаж підіймається або рухається додолу. За певних умов можслва хаотична поведінка системи. Слід відзначити, щчо вертикальні коливання вздовж вертикальної осі відбуваються у два рази швидше, ніж горизонтальні. Положення вантажу, його швидкість та прискорення дозволяють знайти величину натягу підйомного каната у будь-який момент часу, наприклад, за допомогою принципу Даламбера. Натяг діє як на вантаж, так $і$ на оголовок стріли крана, щзо є суттєвою умовою забезпечення стійкості баштового крана, дозволяє визначити безпечні режими підйому або опускання вантажу та навантаження на привод механізму. Існування горизонтальної складової натягу троса при просторовому сферичному русі вантажу суттєво ускладнює вирішення завдання. Одним із способів уникнення цьього негативного явища буде введення управління величиною приводного моменту, який регулює приріст довжини каната за допомогою зміни кутової частоти обертання барабана. Вирішення завдання також можливо пов'язати $з$ введенням додаткових ступенів вільності, таких, як обертання башти крана або його горизонтального переміщення, а також введення механізмів автоматичної зміни довжини кріплення вантажу, що визначає напрями подальших удосконалень.
\end{abstract}

Ключові слова: коливання, нелінійна динаміка, фазовий портрет, маятник, математична модель, рівняння Лагранжа 2-го роду, принџип Даламбера, числовий експеримент. 